\begin{tabular}{|c|c|c|}
\hline Case Reports in & \multicolumn{2}{|c|}{ Case Rep Gastroenterol 2014;8:387-392 } \\
\hline Gastroenterology & $\begin{array}{l}\text { DOI: 10.1159/000369967 } \\
\text { Publisnea onlIne: December 6, } 2014\end{array}$ & $\begin{array}{l}\text { (C) } 2014 \text { S. Karger AG, Basel } \\
1662-0631 / 14 / 0083-0387 \$ 39.50 / 0 \\
\text { www.karger.com/crg }\end{array}$ \\
\hline & \multicolumn{2}{|c|}{$\begin{array}{l}\text { This is an Open Access article licensed under the terms of the Creative Common } \\
\text { Attribution-NonCommercial } 3.0 \text { Unported license (CC BY-NC) (www.karger.com/OA } \\
\text { license), applicable to the online version of the article only. Distribution permitted for non } \\
\text { commercial purposes only. }\end{array}$} \\
\hline
\end{tabular}
commercial purposes only.

\title{
Successful Treatment of Septic Shock due to Spontaneous Esophageal Perforation 96 Hours after Onset by Drainage and Enteral Nutrition
}

\author{
Risako Yamashita $^{\mathrm{a}}$ Shinsuke Takeno ${ }^{\mathrm{a}}$ Ippei Yamana $^{\mathrm{a}}$ Kenji Maki $^{\mathrm{a}}$ \\ Toru Miyake $^{\mathrm{a}}$ Hironari Shiwaku $^{\mathrm{a}}$ Toyoo Shiroshita $^{\mathrm{a}}$ Takeshi Shiraishi $^{\mathrm{b}}$ \\ Akinori Iwasaki $^{\text {b }}$ Yuichi Yamashita ${ }^{a}$ \\ Departments of a Gastroenterological Surgery and ${ }^{b}$ Thoracic Surgery, Fukuoka University \\ Faculty of Medicine, Fukuoka, Japan
}

\section{Key Words}

Spontaneous esophageal perforation · Drainage $\cdot$ Enteral nutrition $\cdot$ Feeding jejunostomy

\begin{abstract}
Spontaneous esophageal perforation is relatively uncommon, but carries a high mortality rate if diagnosis or treatment is delayed. We report the case of a 68-year-old man with spontaneous esophageal perforation who was successfully treated over $96 \mathrm{~h}$ after onset by thoracic drainage and jejunostomy for enteral nutrition. He vomited after drinking alcohol, soon followed by epigastralgia. Heart failure was suspected on admission to another hospital. Spontaneous esophageal perforation was diagnosed $48 \mathrm{~h}$ after admission. Chest tube drainage was performed, but his general condition deteriorated and he was transferred to our hospital. Emergent surgery was performed and esophageal perforation combined with pyothorax and mediastinitis was identified on the left side of the lower esophagus. The left thoracic cavity was rinsed and thoracic drainage was performed. Feeding jejunostomy was performed for postoperative enteral nutrition. Effective drainage and sufficient nutrition management appear extremely valuable in treating spontaneous esophageal perforation.
\end{abstract}


Yamashita et al.: Successful Treatment of Septic Shock due to Spontaneous

Esophageal Perforation 96 Hours after Onset by Drainage and Enteral Nutrition

\section{Introduction}

Spontaneous esophageal perforation (Boerhaave's syndrome) was first described by Hermann Boerhaave in 1724 [1]; it can easily prove fatal if the diagnosis is delayed more than $24 \mathrm{~h}$ after onset, although the mortality has improved recently. Early diagnosis is thus crucial. It has been reported that chest X-ray, endoscopic examination, enhanced esophagography and computed tomography scan were available for rapid and precise diagnosis. However, treatment is often delayed because its diagnosis is confused. The reason might be that the chief complaints, represented by chest pain, chest discomfort, fever, back pain or abdominal pain, are manifold in addition to the rarity of the disease.

In cases diagnosed rapidly, closure and adequate drainage is well known to contribute to improvement of clinical outcome. In contrast, the treatment in cases whose diagnosis was delayed is controversial. Such cases often combine septic shock and the indication for surgery is still disputable taking into consideration the patient's tolerance and surgical stress.

We present a case of spontaneous esophageal perforation in a 68-year-old man treated with emergent surgery $96 \mathrm{~h}$ after onset who was discharged in good health 86 days after emergent surgery. We successfully treated the patient using thoracic drainage and jejunostomy, and report this case with reference to the literature.

\section{Case Report}

The patient was a 68-year-old man who vomited after consuming alcohol, followed shortly thereafter by epigastralgia. He was brought to the hospital by ambulance. On admission, vital signs were as follows: blood pressure $160 / 100 \mathrm{~mm} \mathrm{Hg}$, pulse rate 105 beats/ min, respiratory rate 32 breaths/min, body temperature $38.3^{\circ} \mathrm{C}$ and $\mathrm{SpO}_{2} 95 \%$ (by mask at $3 \mathrm{l} / \mathrm{min}$ ). Blood and laboratory data were as follows: white blood cell count 5,900/ $\mu \mathrm{l}$, red blood cell count $411 \times 10^{4} / \mu \mathrm{l}$, hemoglobin $12.3 \mathrm{~g} / \mathrm{dl}$, neutrophils $81.7 \%$, platelets $9.7 \times 10^{4} / \mu \mathrm{l}$, total protein $6.1 \mathrm{~g} / \mathrm{dl}$, albumin $2.4 \mathrm{~g} / \mathrm{dl}$, blood urea nitrogen $34 \mathrm{mg} / \mathrm{dl}$, creatinine $1.2 \mathrm{mg} / \mathrm{dl}$, creatine phosphokinase $111 \mathrm{IU} / \mathrm{l}$, aspartate aminotransferase $28 \mathrm{IU} / \mathrm{l}$, alanine aminotransferase <10 IU/l, total bilirubin $0.6 \mathrm{mg} / \mathrm{dl}$, Na $142 \mathrm{mEq} / \mathrm{l}, \mathrm{Cl} 108 \mathrm{mEq} / \mathrm{l}$, $\mathrm{K} 4.2 \mathrm{mEq} / \mathrm{l}$, C-reactive protein $40.2 \mathrm{mg} / \mathrm{dl}$, and procalcitonin $12.5 \mathrm{ng} / \mathrm{ml}$.

Chest X-ray showed left pleural effusion and cardiomegaly (fig. 1a). Heart failure was suspected on admission. The patient was diagnosed with spontaneous esophageal perforation $48 \mathrm{~h}$ after admission. Chest tube drainage was performed due to increasing pleural effusion (fig. 1b), but his general condition deteriorated and the patient was diagnosed with sepsis. He was transferred to our hospital $96 \mathrm{~h}$ after onset.

Emergent surgery was performed immediately. The perforated lesion was covered with necrotic tissue. Large amounts of food residue were observed within the left thoracic cavity (fig. 2). A 5-cm-long perforation was identified at the left side of the lower esophagus. The patient also showed pyothorax and mediastinitis. The left thoracic cavity was rinsed with $10 \mathrm{l}$ of saline, and thoracic drainage was performed with chest tubes. A nasoesophageal tube and a transcervical mediastinal tube were inserted simultaneously. Feeding jejunostomy was performed to allow postoperative enteral nutrition.

Postoperatively, blood laboratory data improved (fig. 3). Orally administered contrast medium was seen from the perforated esophagus as a fistula on postoperative day 20 (POD20) (fig. 4a), but had diminished by POD58 (fig. 4b). The lesion of esophageal perforation was covered with regenerated epithelium on endoscopic observation on POD72. Peroral intake was started on POD76 and the patient was discharged from hospital on POD86. 
Yamashita et al.: Successful Treatment of Septic Shock due to Spontaneous

Esophageal Perforation 96 Hours after Onset by Drainage and Enteral Nutrition

\section{Discussion}

Boerhaave initially reported a case of distal esophageal perforation following violent vomiting in 1724 [1]. Recent numerous advances in surgical and nutritional techniques, powerful and selective antibiotics, and better postoperative intensive care have all contributed to significant improvements in the mortality and morbidity associated with esophageal perforation. However, standard or personalized treatment is now controversial because of the variety of disease seriousness. Delayed diagnosis has been considered as one of the reasons why disease seriousness varies because the onset is nonspecific, with symptoms such as vomiting and severe chest or epigastric pain. The incidence of late diagnosis or misdiagnosis has been reported to be $>50 \%$ [2]. Sepsis due to mediastinitis or pyothorax progresses rapidly and the mortality rate doubles if diagnosis is delayed beyond $24 \mathrm{~h}$ [3]. In the present case, the patient complained of severe epigastric pain and dyspnea, and chest X-ray showed left pleural effusion and cardiomegaly. Therefore heart failure was initially suspected and drainage was delayed.

In determining treatment, the general condition of the patient, the degree of contamination and the state of the esophagus around the perforation represent the most important factors. A consensus has been reached that esophageal perforation should be repaired and thoracic and mediastinal drainage should be performed when diagnosis is achieved within

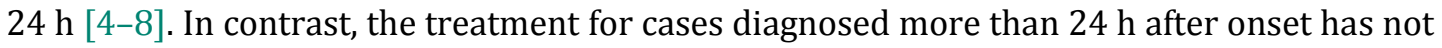
reached a consensus. To date, cases with esophagectomy or simple adequate drainage have been reported. Postoperative leakage reportedly occurs in $83 \%$ of such cases treated over $24 \mathrm{~h}$ after onset [9]. In our case, the patient developed septic shock and perforation extending to the thoracic cavity, so we selected surgical drainage and feeding jejunostomy for postoperative enteral nutrition. In addition to drainage, enteral nutrition reportedly enhances the immune function of the intestinal mucosal barrier against fatal infection $[10,11]$ and has been linked to protection from sepsis or multi-organ failure $[12,13]$. Therefore, the authors believe that adequate drainage and early enteral nutrition in cases such as the present one could be minimally invasive while providing great benefit for spontaneous esophageal perforation with delayed diagnosis, except that it took a longer period until oral intake could be started.

In conclusion, it is unnecessary to say that rapid and precise diagnosis is important, and minimal invasive and adequate treatment based on the patient's condition can rescue in situations of spontaneous esophageal perforation.

\section{Disclosure Statement}

None of the authors declares any competing interest.

\section{References}

1 Derbes VJ, Mitchell RE Jr: Hermann Boerhaave's Atrocis, nec descripti prius, morbi historia, the first translation of the classic case report of rupture of the esophagus, with annotations. Bull Med Libr Assoc 1955;43:217-240.

2 Pate JW, Walker WA, Cole FH Jr, Owen EW, Johnson WH: Spontaneous rupture of the esophagus: a 30-year experience. Ann Thorac Surg 1989;47:689-692.

-3 Brinster CJ, Singhal S, Lee L, Marshall MB, Kaiser LR, Kucharczuk JC: Evolving options in the management of esophageal perforation. Ann Thorac Surg 2004;77:1475-1483. 
Yamashita et al.: Successful Treatment of Septic Shock due to Spontaneous Esophageal Perforation 96 Hours after Onset by Drainage and Enteral Nutrition

4 Abbott OA, Mansour KA, Logan WD Jr, Hatcher CR Jr, Symbas PN: Atraumatic so-called 'spontaneous' rupture of the esophagus. A review of 47 personal cases with comments on a new method of surgical therapy. J Thorac Cardiovasc Surg 1970;59:67-83.

5 Bennett DJ, Deveridge RJ, Wright JS: Spontaneous rupture of the esophagus: a review with reports of six cases. Surgery 1970;68:766-770.

6 Bolooki H, Anderson I, Garcia-Rivera C, Jude JR: Spontaneous rupture of the esophagus: Boerhaave's syndrome. Ann Surg 1971;174:319-324.

7 Froggatt DL, Gunning AJ: Treatment of oesophageal perforation. Thorax 1966;21:524-528.

-8 Keighley MR, Girdwood RW, Ionescu MI, Wooler GH: Spontaneous rupture of the oesophagus. Avoidance of postoperative morbidity. Br J Surg 1972;59:649-652.

-9 Wang N, Razzouk AJ, Safavi A, Gan K, Van Arsdell GS, Burton PM, Fandrich BL, Wood MJ, Hill AC, Vyhmeister EE, Miranda R, Ahn C, Gundry SR: Delayed primary repair of intrathoracic esophageal perforation: is it safe? J Thorac Cardiovasc Surg 1996;111:114-121; discussion 121-122.

10 Windsor AC, Klava A, Somers SS, Guillou PJ, Reynolds JV: Manipulation of local and systemic host defence in the prevention of perioperative sepsis. Br J Surg 1995;82:1460-1467.

11 Goldberg RF, Austen WG Jr, Zhang X, Munene G, Mostafa G, Biswas S, McCormack M, Eberlin KR, Nguyen JT, Tatlidede HS, Warren HS, Narisawa S, Millán JL, Hodin RA: Intestinal alkaline phosphatase is a gut mucosal defense factor maintained by enteral nutrition. Proc Natl Acad Sci USA 2008;105:3551-3556.

12 Bastian L, Weimann A: Immunonutrition in patients after multiple trauma. Br J Nutr 2002;87(suppl 1): S133-S134.

13 Van Leeuwen PA, Boermeester MA, Houdijk AP, Ferwerda CC, Cuesta MA, Meyer S, Wesdorp RI: Clinical significance of translocation. Gut 1994;35(suppl 1):S28-S34.
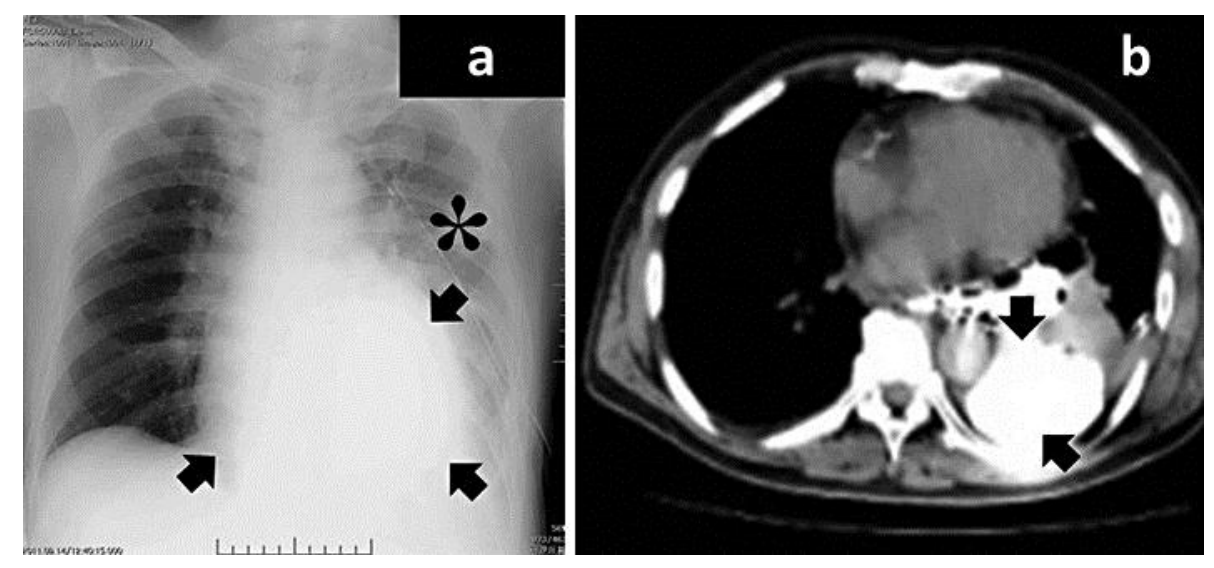

Fig. 1. a Pleural effusion (asterisk) and cardiomegaly (arrows) were seen on chest X-ray. b Outflow of peroral Gastrografin into the left thoracic cavity was detected on computed tomography scan (arrows). 


\begin{tabular}{|c|c|c|}
\hline \multirow{2}{*}{$\begin{array}{l}\text { Case Reports in } \\
\text { Gastroenterology }\end{array}$} & \multicolumn{2}{|c|}{ Case Rep Gastroenterol 2014;8:387-392 } \\
\hline & DOI: $10.1159 / 000369967$ & $\begin{array}{l}\text { (c) } 2014 \text { S. Karger AG, Basel } \\
\text { www.karger.com/crg }\end{array}$ \\
\hline
\end{tabular}

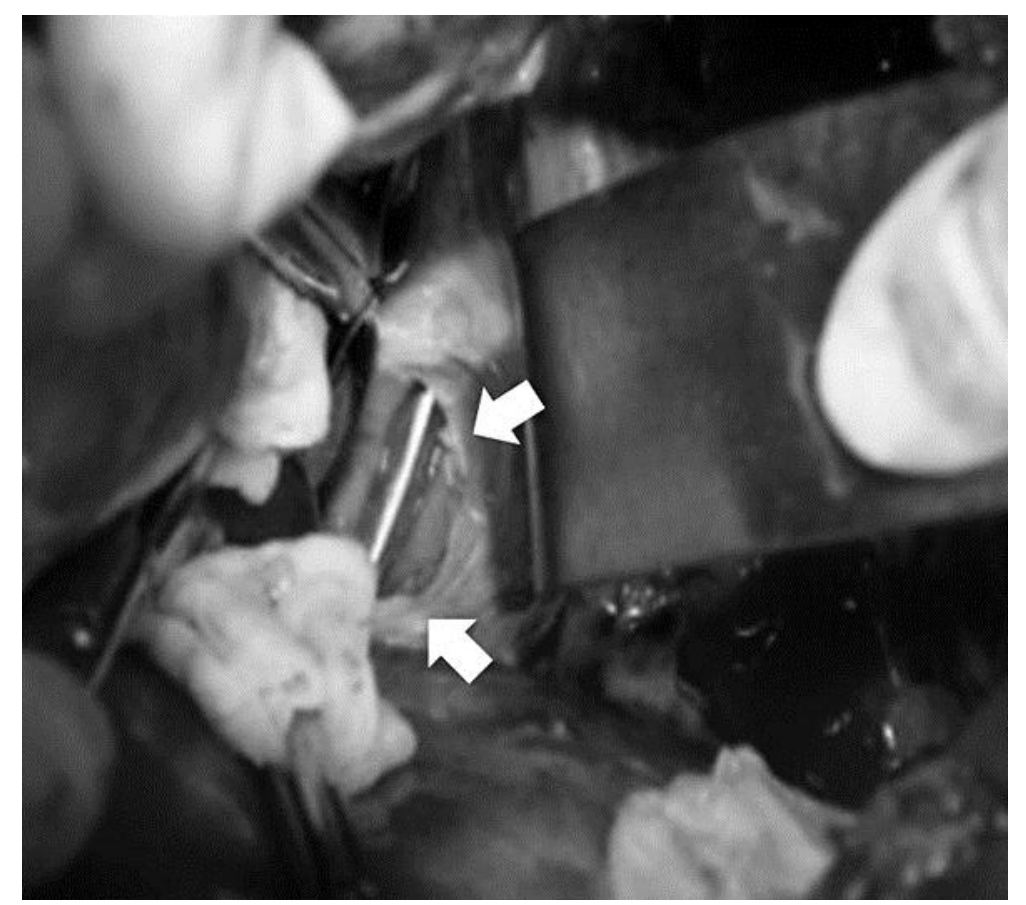

Fig. 2. Esophageal perforation (diameter $5 \mathrm{~cm}$ ) was apparent in the left lower esophagus. A nasogastric tube (arrows) was seen inside the perforated esophagus. Large amounts of food residue were seen within the left thoracic cavity.

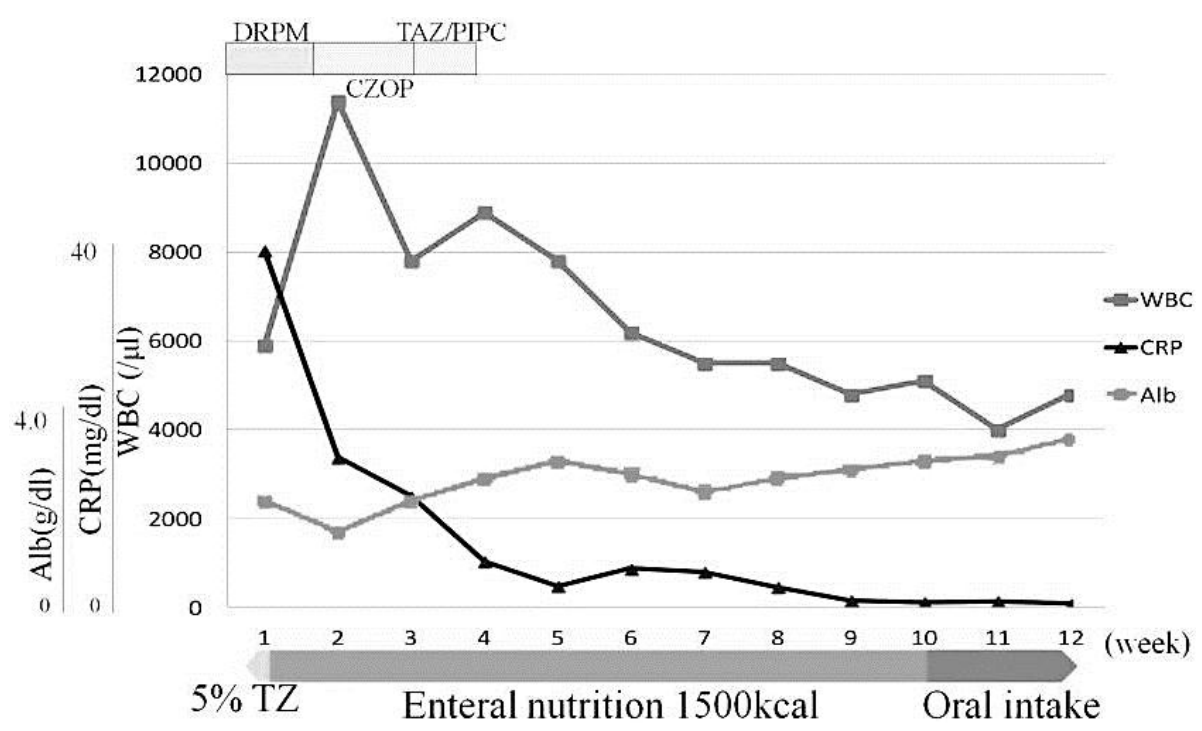

Fig. 3. Postoperatively, blood laboratory data improved favorably. 
Yamashita et al.: Successful Treatment of Septic Shock due to Spontaneous Esophageal Perforation 96 Hours after Onset by Drainage and Enteral Nutrition

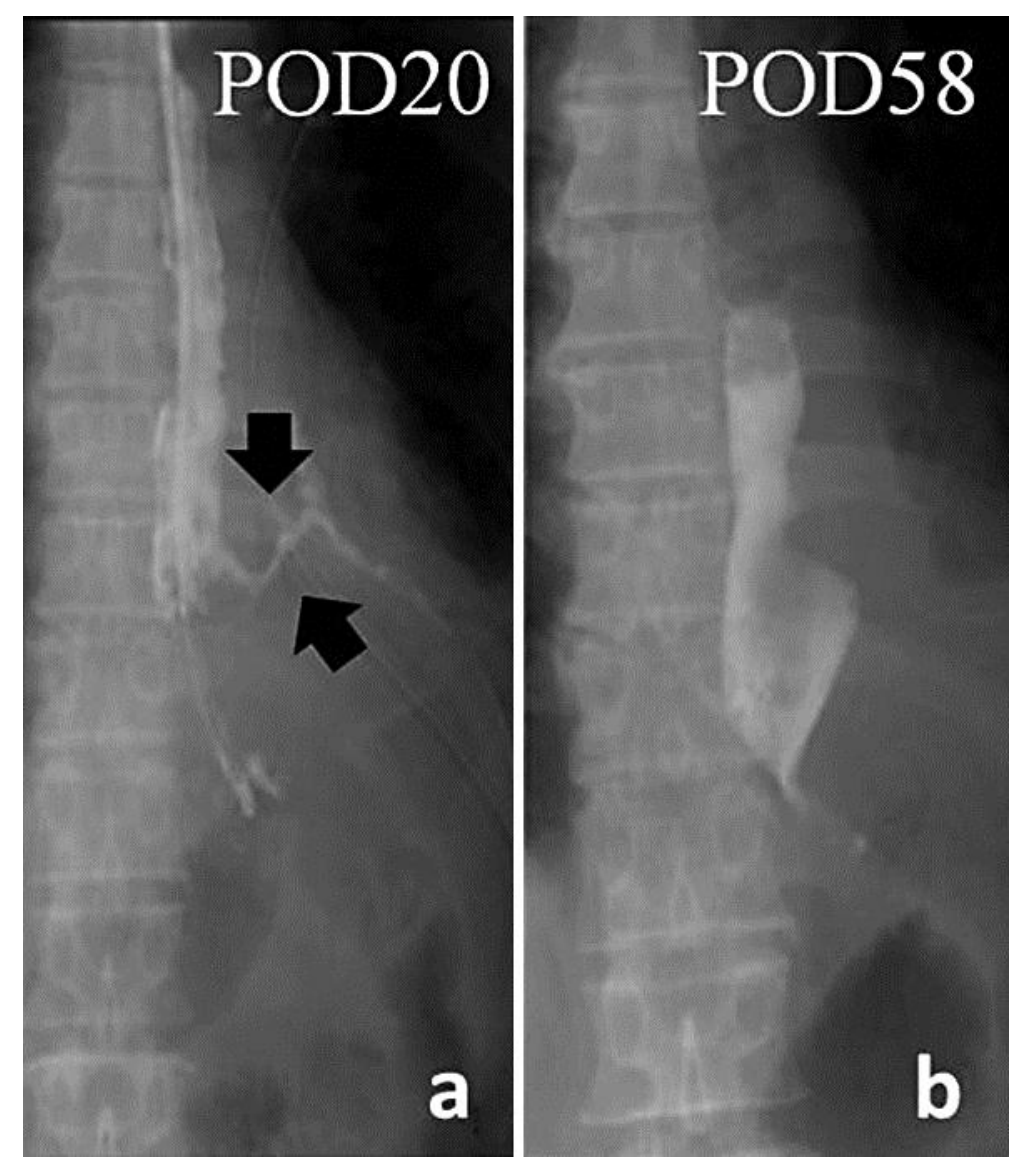

Fig. 4. Peroral contrast medium was seen as a fistula (arrows) from the perforated esophagus on POD20 (a), but was diminished on POD58 (b). 